\title{
Outbreak
}

\section{Escherichia coli (STEC) serotype 0104 outbreak causing haemolytic syndrome (HUS) in Germany and France}

\author{
Salvatore Rubino ${ }^{1,2}$, Piero Cappuccinelli ${ }^{1,2}$, David J. Kelvin ${ }^{1,2,3}$ \\ ${ }^{1}$ Department of Biomedical Sciences, University of Sassari, Sassari, Italy \\ ${ }^{2}$ Journal of Infection in Developing Countries \\ ${ }^{3}$ University Health Network, Toronto, Canada
}

Key words: EAEC; EHEC; HUS; Outbreak O104:H4

J Infect Dev Ctries 2011; 5(6):437-440.

(Received 03 July 2011 -- Accepted 04 July 2011)

Copyright (C) 2011 Rubino et al. This is an open-access article distributed under the Creative Commons Attribution License, which permits unrestricted use, distribution, and reproduction in any medium, provided the original work is properly cited.

At the beginning of May an outbreak of bloody diarrhoea and haemolytic uraemic syndrome (HUS) began in Germany. During the succeeding months following the initial outbreak in Germany, thousands of infections occurred resulting in 877 cases of haemolytic uraemic syndrome (HUS) with 32 deaths and 3,043 cases of enterohaemorrhagic Escherichia coli (EHEC) with 16 deaths [1]. Disturbingly, eight cases of haemolytic uraemic syndrome (HUS) and eight cases of bloody diarrhoea have recently been reported in southern France. It now appears both outbreaks may have been caused by the same pathogen, Escherichia coli O104:H4 [2]. Please see the review article describing in more detail the characteristics of this bacterium by Chattaway et al. [3] that is available open access in this issue of JIDC. Many challenges now face epidemiologists, microbiologists and health regulatory officials in preventing and managing these and future outbreaks of STEC 0104.

\section{Epidemiology}

The German outbreak began in early May 2011, with a peak around the $21 \mathrm{st}-22 \mathrm{nd}$ of the same month. Cases were still reported throughout the first 10 days of June [4]. Interestingly, cases of HUS showed an uneven sex distribution, with women being more affected than men and people over 20 years of age accounting for the vast majority of cases. This distribution is dramatically different from HUS cases involving other strains of STEC. Similarly, the eight cases in France show an uneven distribution of men and women.

Cases in Germany have rapidly declined during June due mainly to prevention measures.

Epidemiological investigations conducted by German authorities link the German outbreak with consuming raw vegetables [5,6]. The French outbreak may also be linked to raw vegetables and there is the strong possibility that sprouted seeds may be the source of both outbreaks. The German outbreak spread mainly in North Germany but cases have been reported in all German states with other sporadic cases identified in 15 countries including Denmark, France, Greece, United Kingdom, Netherlands, Norway, Austria, Spain, Czech Republic, Luxembourg, Poland, Sweden, Switzerland, Canada, and the United States. In many of the sporadic cases a travel history to northern Germany was reported [1]. The total number of travel-related HUS cases now stands at 42 with one death in Sweden [1] (There is a possibility that a Swedish case was not travel related). Seventy cases of non-HUS STEC cases have also been reported [1].

Details on the German outbreak regarding epidemiology and strain characteristics are available in the epidemiology bulletins of the Robert Koch Institute [7], a German federal scientific institute in charge of the study and outbreak. Further information can be obtained from the detailed articles by Askar et al. [8], Struelens et al. [9], Frank et al. [4,5], Scheutz et al. [10] and from the review by Chattaway et al. [3]. 
The clinical and laboratory case definitions used are also listed in the web site of the Robert Koch Institute [11].

Other informative web sites include the European Centre for Disease Prevention and Control (ECDC) (http://ecdc.europa.eu), Eurosurveillance (http://www.eurosurveillance.org/), the European Food Safety Authority (http://www.efsa.europa.eu/), the Health Protection Agency (http://www.hpa.org.uk/), the Centers for Disease Control and Prevention (http://www.cdc.gov/index.htm), and the World Health Organisation (http://www.who.int/en/).

\section{The Pathogen}

Escherichia coli was discovered in the gut in late 1800s by Theodore von Escherich [12], a German bacteriologist-pediatrician, and named Bacterium coli commune. It is the most famous microorganism, defined as the prototype bacteria of nonpathogenic members of the intestinal flora. Some strains with different mechanisms of pathogenicity have developed the capability to cause disease of the gastrointestinal, urinary, or central nervous system.

With the increase in international travel and trade globalization, diarrhoeagenic E. coli has become a worldwide public health threat; however, its identification has become easier with the development of diagnostic tools based on the detection of the virulence trait. Polymerase chain reaction (PCR) methodologies can within hours identify pathogenic strains.

Enteropathogenic Escherichia coli (EPEC), enterotoxigenic $E$. coli (ETEC), enteroinvasive $E$. coli (EIEC), enterohemorrhaghic E. coli (EHEC), enteroaggregative $E$. coli (EAEC) and diffusely adherent $E$. coli (DAEC) have been associated with diarrhoeal disease, especially in developing countries, with ETEC and EAEC the main causes of travellers' diarrhoea $[13,14]$. The novel strain associated with the German and French outbreaks can be considered a chimeric pathotype because it shares virulence characteristics of both EHEC and of the less wellknown EAEC described as enteroaggregative, Shiga toxin/verotoxin-producing $E$. coli (EAggEC STEC/VTEC) [9].

EHEC, also known as both Shigatoxin-producing $E$. coli (STEC) and verocytotoxin-producing $E$. coli (VTEC), was recognized as pathogenic E. coli in 1983 [15], causing two outbreaks associated with the ingestion of undercooked hamburgers at a fast-food restaurant chain in the United States. The virulence of this microbe was documented in the same year [16] with the important observation of the association of sporadic cases of hemolytic uremic syndrome (HUS) defined by the symptoms acute renal failure, thrombocytopenia, and microangiopathic hemolytic anemia, with the isolation of cytotoxin-producing E. coli in bloody stools.

EAEC, defined by its ability to adhere to epithelial cells in a characteristic "stacked-brick" pattern, is increasingly recognized as the causative agents of diarrhoea in children in developing countries, and more recently as the cause of foodborne illness in industrialized countries with a pathogenesis that involves adhesins, toxins, and other factors [17-19]. The first detailed description of an outbreak of EAEC involving infants in a hospital nursery was in Serbia in 1995 [20].

\section{Molecular characterization}

The molecular characteristics of this unusual pathotype, identified serologically as STEC O104:H4, are Shiga toxin 2 (stx2)-positive, Shiga toxin (stx1) and intimin (eae)-negative, and Enterohemolysin negative $(h l y)$. The strain harbours the phage-mediated Shiga toxin as well as the EAEC virulence plasmid encoding aatA (ABC transporter protein), agg $\mathrm{R}$ (master regulator gene of Vir plasmid), aap (secreted protein dispersin gene), agg (AAF/I fimbrial submit gene) and agg [3, 6,9].

Interestingly, pulsed field gel electrophoresis (PFGE) results showed indistinguishable patterns among the strains analyzed causing the outbreak in Germany and two strains isolated in Denmark indicating a single clone [10].

From a microbiological viewpoint, the microorganisms produce extended-spectrum $\beta$ lactamases (ESBLs), enzymes that render the bacteria multi-resistant to many different antibiotics carrying plasmid-borne blaCTX-M-15 and blaTEM-1 genes.

The antimicrobial resistance profile showed resistance to ampicillin, amoxicillin/clavulanic acid, piperacillin/sulbactam, piperacillin/tazobactam, cefuroxime, cefuroxime-axetil, cefoxitin, cefotaxime, cetfazidime, cefpodoxime, streptomycin, nalidixic acid, tetracyclin, trimethoprim/sulfamethoxazol.

Nine isolates from the outbreak have been sequenced to date (21):

- TY2482 (BGI in collaboration with the University Medical Centre HamburgEppendorf. The sequences have been uploaded to NCBI (SRA No: SRA037315.1) and are also available at 
ftp://ftp.genomics.org.cn/pub/Ecoli_TY2482).

- LB226692 (Life Tech in-house in collaboration with the University of Muenster).

- 5 isolates: H112180280 (released earlier with 454 scaffold) plus 4 additional isolates (Health Protection Agency, Colindale, UK).

- 2 isolates, unnamed (Göttingen Genomics Lab, Germany).

Sequence analysis will be important for understanding the evolution of the outbreak strain. In fact, current sequence information indicates that the bacterium is a combination of two strains, $80 \%$ 0104:H4 and 20\% Shiga-toxin producing E. coli, bacteria not previously involved in any $E$. coli outbreaks [22].

\section{Public perception and lessons learned}

It is not surprising that the recent outbreaks of HUS related to infections with Shiga toxin-producing Escherichia coli [STEC] in Germany at the beginning of May gained the front page of newspapers around the world. The seriousness of the illness and the fatalities, coupled with the lack of a definitive source of the causative agent, created uneasiness among the public and even panic within regions of the European Union. The press coverage also increased public uneasiness with alarming reports of a "Super Bug" and "Killer Bug" and "Super Toxic Strain." While the press is in the business of selling newspapers, wild headlines are not helpful and in fact are counterproductive to gaining public trust and cooperation with health agencies in preventing the spread of an outbreak.

The press and media, however, were not alone in inaccurate public statements. It would appear that public officials making statements alleging that the contaminated food source originated in Spain were also unfounded. This in turn caused economic stress to Spanish farmers and political strife within countries in the EU. This again undermined public confidence and international cooperation in managing the outbreak.

We can only expect to see future outbreaks similar to what we witnessed in Germany and are currently seeing in France. It is apparent that these types of outbreaks are not solely a consequence of health conditions in developing countries. Clearly one of the important and positive lessons from the German outbreak is the cooperation and teamwork of networks and health agencies. This type of coordination can in a short time produce valuable epidemiological information, as well as pathogen isolation, characterization and sequencing. Information is vital to developing public health measures to limit and curtail outbreaks. Perhaps in the future the release of more accurate information will ensure public trust in government initiatives to deal with health threats.

While Germany is not a developing nation, the handling of the outbreak can be used as a model to build a strategic plan for developing nations. First a well-coordinated network that shares information on outbreaks in developing countries will be invaluable. Networks help bring expertise and technology to resource-limited areas in a timely manner. Here at JIDC the Editors welcome input from our readers to identify and report on regional outbreaks and special issues that may arise. As for the European outbreaks of E. coli O104, all countries should be on alert to this pathogen, and public health agencies need to arm themselves with diagnostic tools to rapidly identify this new pathogen.

\section{References}

1. World Health Organization Regional Office for Europe (2011) http://www.euro.who.int/en/what-we-do/healthtopics/emergencies/international-healthregulations/news/news/2011/06/ehec-outbreak-update-22. Last accessed 30 June 2011.

2. World Health Organization Regional Office for Europe (2011) http://www.euro.who.int/en/what-we-do/healthtopics/emergencies/international-health-

regulations/news/news/2011/07/outbreaks-of-e.-colio104h4-infection-whoeurope-gives-public-health-advice. Last accessed 30 June 2011.

3. Chattaway MA, Dallman T, Okeke IN, Wain J (2011) Enteroaggregative E. coli O104 from an outbreak of HUS in Germany 2011, could it happen again? J Infect Dev Ctries 2011; 5(6):425-436.

4. Frank C, Werber D, Cramer JP, Askar M, Faber M, an der Heiden M, Bernard H, Fruth A, Prager R, Spode A, Wadl M, Zoufaly A, Jordan S, Stark K, Krause G for the HUS Investigation Team (2011) Epidemic Profile of ShigaToxin-Producing Escherichia coli O104:H4 Outbreak in Germany - Preliminary Report. N Engl J Med 22 June 2011. Epub ahead of print. (10.1056/NEJMoa1 106483). Last accessed 30 June 2011.

5. Frank C, Faber MS, Askar M, Bernard H, Fruth A, Gilsdorf A, Höhle M, Karch H, Krause G, Prager R, Spode A, Stark K, Werber D (2011) Large and ongoing outbreak of haemolytic uraemic syndrome, Germany, May 2011. Euro Surveill 16: 16June: pii=19878. Last accessed 30 June 2011.

6. European Food Safety Authority (2011) Urgent advice on the public health risk of Shiga-toxin producing Escherichia coli in fresh vegetables. EFSA Journal 9:2274. [50 pp.] doi:10.2903/j.efsa.2011.2274. 
7. Robert Koch Institute (RKI) (2011) The epidemiology bulletin of the Koch Institute http://www.rki.de/cln_169/nn_467482/DE/Content/Infekt/E pidBull/Archiv/2011/22 11, templateId=raw,property=publ icationFile.pdf/22_11.pdf. Last accessed 30 June 2011.

8. Askar M, Faber MS, Frank C, Bernard H, Gilsdorf A, Fruth A, Prager R, Höhle M, Suess T, Wadl M, Krause G, Stark $\mathrm{K}$, Werber D (2011) Update on the ongoing outbreak of haemolytic uraemic syndrome due to Shiga toxin-producing Escherichia coli (STEC) serotype O104, Germany, May 2011. Euro Surveill 16, 02June:pii=19883. Last accessed 30 June 2011.

9. Struelens MJ, Palm D, Takkinen J (2011) Enteroaggregative, Shiga toxin-producing Escherichia coli O104:H4 outbreak: new microbiological findings boost coordinated investigations by European public health laboratories. Euro Surveill 16: pii=19890. Last accessed 30 June 2011

10. Scheutz F, Møller Nielsen E, Frimodt-Møller J, Boisen N, Morabito S, Tozzoli R, Nataro JP, Caprioli A (2011) Characteristics of the enteroaggregative Shiga toxin/verotoxin-producing Escherichia coli O104:H4 strain causing the outbreak of haemolytic uraemic syndrome in Germany, May to June 2011. Euro Surveill 16:pii=19889. Last accessed 30 June 2011

11. Robert Koch Institute (RKI). Case definition for HUS-cases associated with the outbreak in the spring 2011 in Germany. HUS-Outbreak_Case-Definition_2011-06-01_ENG.doc.

Available

from: http://www.rki.de/cln_116/nn_217400/EN/Home/HUS_Ca se definition,templateId=raw,property=publicationFile.pdf /HUS_Case_definition.pdf. Last accessed 30 June 2011.

12. Shulman ST, Friedmann HC, Sims RH (2007) Theodor Escherich: The First Pediatric Infectious Diseases Physician? Clin Infect Dis. 45: 1025-1029.

13. Nataro JP and Kaper JB (1998) Diarrheagenic Escherichia coli Microbiol Rev 11: 142-201.

14. Okeke IN (2009) Diarrheagenic Escherichia coli in subSaharan Africa: Status, Uncertainties and Necessities. J Infect Dev Ctries 3: 817-842.
15. Riley LW, Remis RS, Helgerson SD, McGee HB, Wells JG, Davis BR, Hebert RJ, Olcott ES, Johnson LM, Hargrett NT, Blake PA, Cohen ML (1983) Hemorrhagic colitis associated with a rare Escherichia coli serotype. N Engl J Med 308: 681-685.

16. Karmali MA, Steele BT, Petric M, Lim C (1983) Sporadic cases of haemolytic uremic syndrome associated with faecal cytotoxin and cytotoxin-producing Escherichia coli in stools. Lancet 19: 619-620.

17. Nataro JP (2005) Enteroaggregative Escherichia coli pathogenesis. Curr Opin Gastroenterol 21: 4-8.

18. Nataro JP, Steiner T, Guerrant R.L. (1998) Enteroaggregative Escherichia coli Emerg Infect Dis 4: 251251.

19. Okeke IN and Nataro JP (2001) Enteroaggregative Escherichia coli, The Lancet Infectious Diseases 5: 304313.

20. Cobeljic M, Miljkovic-Selimovic B, Paunovic-Todosijevic D, Velickovic Z, Lepsanovic Z, Zec N, Savić D, R. Ilić R, Konstantinović S, B. Jovanovic B , Kostić V (1996) Enteroaggregative Escherichia coli associated with an outbreak of diarrhoea in a neonatal nursery ward. Epidemiol Infect 117: 111-116.

21. E. coli O104:H4 Genome Analysis Crowdsourcing (2011) https://github.com/ehec-outbreak-crowdsourced/BGI-dataanalysis/wiki.

22. BGI Europe (2011) BGI Sequences Genome of the Deadly E. Coli in Germany and Reveals New Super-Toxic Strain. http://www.bgisequence.com/eu/index.php?cID=194. Last accessed XXXX.

\section{Corresponding author}

Salvatore Rubino

Dipartimento di Scienze Biomediche

Università degli Studi di Sassari

Viale San Pietro 43 B, 07100 Sassari, Italy tel. 0039-079228302 fax 0039-079212345

srubino@jidc.org

Conflict of interests: No conflict of interests is declared. 